Перед нами стоїть безліч завдань. І головне з них те, щңо Азербайджан має вести власну незалежну політику. Наш народ може розвиватися виключно в умовах незалежності. Ми століттями були позбавлені незалежннсті й не могли зробити власного вибору. Сьогодні ми щцасливі, щз жсивемо як незалежна краӥна, як вільний народ і наша доля в наших руках. Захист і зміцнення нашої незалежності - одне з найголовніших завдань.

Ільхам Алієв Президент Азербайджанської Республіки

UOT 328; 342.5; 351/354; UOT 32:93/94

doi: 10.32620/gch.2019.4.03

Абдулалі Абдулласв

\title{
СТРУКТУРНІ РЕФОРМИ В АЗЕРБАЙДЖАНІ ЯК ЧАСТИНА ЕФЕКТИВНОСТІ ДЕМОКРАТИЧНОГО УПРАВЛІННЯ
}

У статті проаналізовано структурні реформи в Азербайджані як частину ефективності демократичного управління. Підкреслено, щзо під керівництвом загальнонаціонального лідера Гейдара Алієва було створено нову судову систему; конституиійний контроль; установи, уповноважені із прав людини, засновані на принципі демократичного правосуддя; удосконалено діяльність правоохоронних органів; розширено діяльність засобів масової інформації; сформовано ефективні захисні механізми щзодо забезпечення прав громадян.

Ключові слова: реформи, державне управління, державні органи, начіональний розвиток, інноваційний процес.

The article analyzes structural reforms in Azerbaijan as part of the effectiveness of democratic governance. It is underlined that a new judicial system was created under the leadership of the national leader Heydar Aliyev; constitutional control; institutions empowered by human rights, based on the principle of democratic justice; the activities of law enforcement agencies have been improved; media activities have been expanded; effective safeguards have been put in place to ensure citizens' rights.

Keywords: reforms, public administration, public authorities, national development, innovation process.

Сьогодні Азербайджан усебічно й динамічно розвивається, і в цій справі вкрай важлива адаптація управління до сучасних вимог, а також постійне ведення структурних реформ для забезпечення гнучкості й ефективності. Глибокі структурні правові й інституціональні реформи, регулярно проводжувані в нашій країні, приносять свої плоди. У результаті зусиль Гейдара Алієва наша країна, розвиваючись як світська, правова й демократична держава, створила нормативно-правову базу, яка відповідає найвищим стандартам, що забезпечують свободу громадян і верховенство закону. Таким чином, під керівництвом нашого загальнонаціонального лідера Гейдара 
Алієва були створені нова судова система; конституційний контроль; установи, уповноважені з прав людини, засновані на принципі демократичного правосуддя; удосконалена діяльність правоохоронних органів; розширена діяльність засобів масової інформації; сформовано ефективні захисні механізми щодо забезпечення прав громадян.

Загальнонаціональний лідер азербайджанського народу Гейдар Алієв, який надавав особливого значення державності, удосконаленню системи законодавства й управління, а також необхідності реформ у вказаних сферах, в одному зі своїх виступів сказав таке: «Ми взяли курс правового, світського та демократичного державного устрою. Тому ми повинні підняти всю законодавчу базу країни на рівень сучасних світових стандартів, поглибити правові реформи, а особливо здійснити реформи в галузі юриспруденції, засновані на досвіді світової цивілізації. Ви можете бути повністю впевнені в тому, що ми здійснимо все це» [23].

Тим самим покладено основу громадянського суспільства, що спирається на закон і справедливість, і створено надійний фундамент для його вдосконалювання. Нинішні реформи також прагнуть забезпечити стабільність досягнень і відповідати закликам сучасного світу. У цьому процесі, у державному й соціальному управлінні, закордонний досвід творчо використовується в інтересах стійкого національного розвитку. Ураховуючи міжнародні досягнення, особливості національної культури й можливості держави, правові реформи охоплюють такі заходи, як підготовка законів та інших нормативно-правових актів, розширення правової інформаційної системи, реформа судової та в цілому правоохоронної системи, пропаганда й вивчення законів серед населення. Успішний результат кожної реформи в першу чергу залежить від його актуальності, оточення, а найголовніше - від втілення в собі прав і свобод громадян і суспільної підтримки в заходах. Головний фактор і важливе стратегічне завдання, що визначає майбутнє Азербайджану, - підвищення ефективності державної діяльності. Саме тому в останні роки в Азербайджані розширюються реформи, які охоплюють усі сфери державної системи управління. Головна мета цих реформ - створення відповідної системи управління щодо виниклих нових завдань, забезпечення відповідальності, прозорості та звітності державних органів перед народом. У числі головних завдань управлінських реформ у нашій державі можна зазначити такі процеси, як створення конкурентного середовища в частині надання державних послуг, націлених для поліпшення їх якості, застосування системи стратегічного планування державного розвитку в роботі уряду, залучення громадськості в процесі прийняття державних рішень, концентрація ресурсів для вирішення пріоритетних завдань.

3 метою забезпечення стійкого розвитку Азербайджану всі проведені реформи не пройшли повз судово-правову систему. Реформи у сфері судово-правової системи $\epsilon$ важливими складовими реформ системи державного управління. Таким чином, реформи повинні грунтуватися на законодавчій базі, а судово-правова система повинна адаптуватися до нових реалій. Незалежна судова влада, яка звітує перед народом, є вирішальним чинником, що обмежує й запобігає можливості зловживання влади організаціями, які належать до двох інших галузей державної влади. Водночас 
успішне завершення економічних реформ і розвиток приватного сектору були б неможливими без правових основ і судової системи, що ефективно захищає право приватної власності, здійснює контроль виконання договірних зобов'язань, захищає права економічних суб'єктів, створює стабільні умови для місцевих і закордонних інвесторів, надає допомогу в урегулюванні ринкових відносин. Указ Президента Азербайджанської Республіки про поглиблення реформ судово-правової системи від 3 квітня 2019 р. спрямований на поглиблення реформ, адже перехід у нову економічну формацію вимагає поглиблення цих реформ. Цим указом Президент країни поставив перед собою завдання у вигляді усунення негативних випадків, що відбуваються в судах, забезпечення прозорості, залучення грамотних суддів у процеси у всіх сферах, незалежних діяльності системи. Крім того, це дало поштовх до введення фундаментальних змін у судовій системі й усебічного використання переваг застосовуваних сучасних інформаційних технологій для більшого вдосконалення й прогресування цієї системи. Заходи, передбачені в указі, створюють реальні можливості для усунення труднощів, із якими стикаються юристи в процесі захисту прав і законних інтересів, а також у наданні якісної юридичної допомоги громадянам країни. Реформа спрямована на забезпечення й соціальний захист суддів, а також на розвиток підприємництва, захист інтересів підприємців і заохочення інвестицій. Відображення в документі справ, пов'язаних 3 електронним судом, слугуватиме зміцненню правової визначеності. Цей указ є показником, що підтверджує інтерес Президента у створенні ефективної системи соціального захисту й інших важливих реформ шляхом укріплення людського капіталу для постійного захисту інтересу народу.

Світова практика показує, що розвиток людського капіталу приводить до збільшення доходів країни й населення. За сучасними вимогами проблема виміру економічної ефективності формування людського капіталу та поліпшення його використання має важливе значення. Як частина реформацій, здійснених на шляху до трансформації економіки Азербайджану, тривають заходи щодо забезпечення безперервності людського капіталу й збільшення продуктивності праці. Цей процес здійснюється на двох рівнях: шляхом поліпшення якості освіти на всіх стадіях для формування людського капіталу й стимулювання інвестування в частині досліджень i вдосконалень безперервного розвитку людського капіталу для забезпечення поліпшення продуктивності праці. В оприлюдненому звіті Всесвітнього економічного форуму «Індекс людського капіталу» на 2015 р. Азербайджан посів серединну позицію (63-є місце) серед 124 країн, обігнавши такі країни, як Туреччина, Китай, Індонезія та Кувейт. А в оприлюдненому організацією Глобальному звіті конкурентоспроможності за 2016-2017 рр. наша країна посіла 37-е місце серед 138 країн. Це вказує на наявність можливостей збільшення людського капіталу та конкурентоспроможності Азербайджану. За минулі роки в Азербайджані було визначено й ужито низку заходів у зв'язку з розвитком людського капіталу. На цей момент у всіх здійснюваних стратегіях, державних програмах і концепціях розвиток людського капіталу висунуто на передній план. У Концепції розвитку «Азербайджан - 2020: Погляд у майбутнє» i в «Державній стратегії 3 розвитку освіти в 
Азербайджанській Республіці» розвиток людського капіталу, а також розвиток, заснований на знаннях та інноваціях, є пріоритетом.

Продовження реформ за напрямком розвитку людського капіталу в Азербайджані є дуже важливим для поліпшення якості освіти та створення гнучкого механізму управління відносин «наука - освіта - виробництво». Майбутнє Азербайджану, сталий розвиток його економіки неможливо уявити без збільшення ролі науки й освіти. Адже в країнах, де рівень людського капіталу високий, соціально-економічні реформи проходять більш успішно, політична свідомість і культура прагне вгору, громадяни беруть активну участь у процесі зміцнення соціально-орієнтованої держави. I не випадково, що Президент Азербайджанської Республіки пан Ільхам Алієв багаторазово зазначав, що збільшення ролі людського фактору є однією з головних цілей економічної політики країни.

Принцип паралелі економічних, політичних і правових реформ за останні 10 років становить фундаментальну основу процесу демократизації Азербайджану та в цілому адаптації ліберальних цінностей суспільства. Президент Ільхам Алієв багаторазово зазначав, що в країні, де демократичні процеси не ведуться в регулярному порядку, високі показники в економічній сфері, почесне становище на міжнародній арені й інтеграція у світову економіку неможливі. Водночас в економічно не розвиненій державі спроби, спрямовані на демократизацію та створення громадянського суспільства, не увінчаються успіхом [12]. Дотримуючись саме цього погляду, Президент Азербайджану пан Ільхам Алієв уважає важливим підхід до двох факторів у єдиному порядку й реальним довгостроковий розвиток країни за умови паралельного проведення демократичних та економічних реформ.

Інше важливе завдання, що стоїть на шляху поглиблених реформ, - це забезпечення економічного стимулювання через структурні зміни й ефективне використання трудових ресурсів. Із визнанням міжнародним співтовариством успіхів Азербайджану у сфері соціально-економічного розвитку політичний вплив нашої країни на світовій арені збільшується. Провідні світові міжнародні організації й установи ставлять за приклад країнам, що розвиваються, усебічні реформи, реалізовані нашою країною. Впливові засоби масової інформації та міжнародні рейтингові центри високо оцінюють успіхи Азербайджану в різних сферах. 31 жовтня 2018 р. в оприлюдненому звіті Світового Банку «Doing Business 2019» Азербайджан, увійшовши до десятки в списку країн-реформаторів, був оголошений країною 3 найбільшою кількістю проведених реформ. У новому звіті, порівняно 32017 р., Азербайджан, піднявшись на 32 пункти, посів 25-е місце серед 190 країн і, обігнавши безліч держав, став лідером серед країн Співдружності Незалежних Держав. Досягнення нашої країни у сфері соціально-економічного розвитку є кращим доказом ефективності економічних реформ і моделі розвитку в Азербайджані. В умовах поширення глобальної економічної кризи Азербайджан, будучи невід'ємною частиною світової економіки, зміг вибратися зі становища 3 мінімальними втратами. Одна $з$ головних причин, чому глобальна криза не змогла серйозно поширитися в Азербайджані, - це формування сприятливого інвестиційного й бізнес-середовища, ефективна реалізація продуктивного потенціалу областей, сприяння внутрішньому 
виробництву й розширення можливостей бізнесменів. Усе це вказує, що економічний розвиток нашої країни вступив на новий рівень якості. Головна мета нового рівня досягти збільшення конкурентоспроможності національної економіки, а також активна й ефективна інтеграції в систему світового сільського господарства. В указах, підписаних Президентом Азербайджанської Республіки паном Ільхамом Алієвим, і в затверджених ним документах економічної політики визначені необхідні завдання для реалізації цієї мети.

Тут окремо потрібно відзначити роль певних Державних програм щодо соціально-економічного розвитку регіонів. Як було зазначено в указі Президента Ільхама Алієва від 29 січня про затвердження «Державної програми соціальноекономічного розвитку регіонів Азербайджанської Республіки 2019-2023 років», розвиток регіонів Азербайджанської Республіки є важливою складовою стійкого соціально-економічного розвитку, здійснюваного в країні. За 2004-2018 р. виконання певних Державних програм із соціально-економічного розвитку регіонів внутрішній валовий продукт за не нафтовим сектором збільшився у 2,8 разу, за промисловістю у 2,6 разу, за сільським господарством - 1,7 разу. Завдяки цільовим діям, виконаним за цей строк, у країні було створено 2 мільйони робочих місць, 1,5 мільйона 3 яких $\epsilon$ постійними; відкрилося більше 100 тисяч підприємств, безробіття знизилося до 5 відсотків, а рівень бідності - до 5,1 відсотка.

Діяльності бізнесменів в Азербайджані приділяють належну увагу, а також важливого значення надають вирішенню проблем, із якими вони стикаються. Це відображається в здійсненні низки заходів щодо забезпечення швидкого розвитку приватного, не нафтового сектору. Із цього приводу Президент Ільхам Алієв сказав: «Мета в тому, щоб через кілька років повністю усунути залежність наших економічних можливостей від нафтового фактору. У нас є на це можливість, і я впевнений, що розвиток не нафтового сектору ще більше розшириться за рахунок державної підтримки, а також завдяки діяльності приватного сектору. Кредити, які ми даємо підприємцям протягом кількох років, також благотворно діють. Завдяки цим кредитам створюються фабрики, переробні підприємства, розвивається приватний бізнес. У загальній частці нашої економіки приватний бізнес посідає досить значну частину. Більше $80 \%$ економіки Азербайджану були влаштовані на основі приватного сектору».

Завдяки великомасштабній політиці індустріалізації Президента Ільхама Алієва, здійснюваній відповідно до стратегічної лінії з розвитку промисловості, створюються сотнями конкурентоспроможні й орієнтовані на експорт підприємства, у задоволенні попиту частка місцевих продукцій значно підвищується, обсяг експорту збільшується.

У результаті виконання Стратегічної Дорожньої Карти за перспективами національної економіки, що забезпечують макроекономічну координацію й макроекономічну стабільність, здійснено роботи за такими напрямами, як правила бюджету («золоте правило»), середньострокова структура видатків, стратегія щодо державного боргу, грошова програма, податкові й митні реформи, програма приватизації, Стратегія зайнятості, Система страхування від безробіття й застосування пілотної версії обов'язкового медичного страхування. Бізнес-реформи 
охоплюють такі сфери, як купівля, електронний суд, підключення до електрики, дозвіл на будівництво, реєстрація майна, оцінка рухомого майна, електронний рахунок-фактура, «Зелений коридор», експортна онлайн-заявка. Створені платформи Azexport.az i Цифровий Торговельний Вузол; використані такі методи просування, як торговельні представництва, експортні місії, торговельні доми й експортні субсидії. Головні заходи, очікувані в 2019-2020 pр. за перспективою національної економіки, такі: формування адекватних економічних очікувань, затвердження передових корпоративних стандартів управління, заохочення міжбанкового грошового ринку, інститут маркет-мейкерства, заохочення безготівкових розрахунків, розвиток ринку капіталу, приватизація в пріоритетних секторах, перехід зі школи «пам'яті» до школи «мислення» й т. д. [22].

Відповідно до політичної волі керівника країни, потужний економічний розвиток нашої країни доповнюється глибокою соціальною політикою. До прогресивних заходів щодо розвитку належать посилення економічного потенціалу країни, розвиток не нафтового сектору, створення умов для відкриття робочих місць, розвиток підприємництва, збільшення в істотному порядку обсягу й націленості соціальних послуг, скорочення бідності й т. д.

Важливе рішення у зв'язку з проблемними кредитами, у межах великого соціального пакета, інтенсивно реалізованого 3 початку 2019 р., варте особливої уваги. Соціальна важливість указу, підписаного Президентом Ільхамом Алієвим 28 лютого 2019 р. «Про заходи щодо вирішення проблемних кредитів фізичних осіб Азербайджанської Республіки», занадто велика. Згідно з указом, підписаним главою держави, втрати, завдані людям унаслідок девальвації, компенсуються державою. Безумовно, не тільки цей указ, але й інші соціально спрямовані революційні укази $\epsilon$ факторами, що демонструють використання потенціалу держави на благо народу. На сьогодні соціальна політика визначена як пріоритетний напрям. Реалії цієї тривалої політики знаходять своє конкретне відображення в серйозних інфраструктурних проектах, збільшенні зарплат і соціальних пільг та в цілому в процвітанні людей. Натепер Азербайджан, зі своєю чудовою соціальною політикою, може вважатися прикладом для всього світу.

Шляхом здійснення послідовної роботи зі збільшення виплат, спрямованих на соціально вразливі групи, включаючи пенсії-пільги, і розширення сфери діяльності системи соціального забезпечення підтримується соціальна стабільність. Унаслідок цього 3 року в рік розширюються соціальні програми Міністерства праці та соціального захисту, спрямовані на родини мучеників та інвалідів, на ветеранів війни. За минулий період родини більш ніж 6200 інвалідів і мучеників були забезпечені квартирами міністерством. Із відповідним указом Президента Ільхама Алієва в 2018 р. у результаті виділення додаткових коштів кількість квартир, виділених на родини мучеників та інвалідів, зросла втричі, досягнувши тим самим позначки 626 квартир. Забезпечення легковими автомобілями інвалідів війни та інших осіб, прирівнюваних до них, також входить у список цих справ. На сьогодні 6144 осіб, що входять до цієї групи, були забезпечені автомобілями. Міністерство забезпечує пенсією понад 1,3 мільйона чоловік, приблизно 500 тисяч отримують пільги, понад 60 тисяч - 
щомісячну Президентську стипендію, 200 тисяч - соціальну допомогу, майже 16 тисяч - мобільні й стаціонарні соціальні послуги. Із відповідним указом Президента, на цей момент у спадок 9,5 тисячі загиблих військовослужбовців була внесена разова виплата. Протягом року понад 10 тисяч інвалідів отримують реабілітаційні послуги для відновлення здоров'я, здійснюється реабілітація 32-35 тисяч осіб з обмеженими фізичними можливостями. На основі відповідних указів Президента Ільхама Алієва, разом із регулярним збільшенням виплат із соціального забезпечення, створюються нові реабілітаційні центри в регіонах для осіб 3 обмеженими можливостями, забезпечується створення реабілітаційних центрів на рівні сучасних вимог. За останні роки, за дорученням глави держави, з уведенням у експлуатацію нових соціальних реабілітаційних центрів i комплексів, що перебувають у підпорядкуванні міністерства, сфера соціальних послуг значно розширилася.

3 указом «Про додаткові заходи щодо удосконалення управління в сфері зайнятості населення, праці, соціальний захист і забезпечення», підписаним главою держави 9 серпня 2018 р., метою Агентства Стійкого і Оперативного Соціального Забезпечення (СОC3), що перебуває в підпорядкуванні Міністерства Праці та Соціального Захисту Населення, є забезпечення поліпшення якості послуг у сфері зайнятості, праці, інвалідності та соціального захисту, посилення прозорості в цих службах, застосування інноваційних рішень і добробут громадян.

3 метою підвищення ефективності діяльності органів державного управління було продемонстровано політичне управління державою в боротьбі 3 негативною економічною ситуацією й були ухвалені важливі заходи щодо боротьби $з$ корупцією. Антикорупційні заходи є одним із пріоритетних напрямків політичної діяльності Президента Ільхама Алієва, лібералізація економіки в нашій країні, усунення бюрократичних перешкод, установлення здорових відносин між державними службовцями, інституційні реформи для забезпечення прозорості й підзвітності, а також для боротьби з такою корупцією.

Глибина реформ в Азербайджані, прогрес, досягнутий у боротьбі з корупцією, більший масштаб інституційних змін і заходи, ухвалені для боротьби з корупцією, призводять до того, що Азербайджан отримує більш високі показники в «Індексі сприйняття корупції» (Corruption Perceptions Index, CPI). «Прозорість - це питання, яке визначає майбутнє кожної країни. Тому що без прозорості ми не можемо проводити будь-які реформи, а країна економічно або політично не може розвиватися швидко», - говорив Президент Ільхам Алієв, який зробив інноваційні кроки в межах реформ, спрямованих на поліпшення функціонування державних структур i підвищення прозорості. 13 липня 2012 р. Президентом створено Державне агентство 3 обслуговування громадян i соціальних інновацій при Президенті. Створення сервісних центрів «ASAN», які стали азербайджанським брендом із поліпшення послуг, що надаються громадянам у межах цієї системи, обмежили внутрішні корупційні й бюрократичні перешкоди. Відповідно до міжнародної практики портал «Електронного Уряду», що грунтується на принципах «єдиного вікна» й інтегрує електронні послуги, що надаються державними органами, використовується для більш ефективного спілкування з громадянами. В останні роки кількість електронних 
послуг зростає, немає жодного державного органу, який не долучився б до порталу електронного уряду. Надання послуг електронного уряду, заснованих на цих принципах, дасть змогу заощадити час i бюджетні витрати, підвищити продуктивність і ефективність, отримати позитивні результати й багато іншого. Це забезпечить прискорений перехід до електронних послуг за рахунок використання сучасних інновацій паралельно 3 підвищенням прозорості в діяльності державних органів. У результаті створюються сприятливі умови для активної участі громадян у державному управлінні, а також громадського контролю над процесами демократизації, освіти й модернізації в державі. Конкурентоспроможність нашої країни на міжнародному рівні стала можливою завдяки створенню універсальної моделі життєдіяльності державного управління, сучасним стратегіям і технологіям управління, що забезпечують високий національний розвиток і якість роботи.

Експерти відзначають, що проведені урядом Азербайджану реформи дозволили домогтися значних успіхів у боротьбі з корупцією. Останній «Барометр Глобальної Корупції» Міжнародної Організації Прозорості показує, що наша країна досягла значних успіхів у боротьбі з корупцією та зниження рівня корупції. Згідно зі звітом, 79\% респондентів в Азербайджані не вважають корупцію головною проблемою, що стоїть перед нашим суспільством. Цей показник кращий, ніж у середньому за Свропейським Союзом (68\%) і пострадянськими країнами (66\%). Антикорупційна Група Ради Європи (GRECO), Комітет 3 Боротьби 3 Відмивання Грошей (MONEYVAL), Антикорупційна Мережа Організації Економічного Розвитку i Співробітництва (OECD) i Азербайджан, який успішно пройшов відповідні раунди оцінки підкомітетів ООН, домігся великих успіхів у боротьбі з корупцією, і цей процес буде сприяти подальшому підвищенню добробуту своїх громадян [3].

3 метою підвищення ефективності діяльності державних органів відповідно до сучасних стандартів у 2007-2011 pp. була реалізована Національна Стратегія Підвищення Прозорості та Боротьби з Корупцією, а також були прийняті Національні Плани Дій зі Сприяння Відкритого Уряду.

Після переобрання Ільхама Алієва до Кабінету Міністрів відбулися значні зміни, на керівні посади в уряді були призначені молоді кадри з сучасними управлінськими знаннями й навичками. Кадрова політика, яка широко вітається громадською думкою, мала значний вплив на гнучкість і ефективність державних органів. У той же час була врахована необхідність підвищення ефективності системи державного управління й формування нової структури управління, що відповідає сучасним вимогам. 14 січня 2019 р. Президент Азербайджану підписав указ про додаткові заходи щодо вдосконалення державного управління 3 метою оптимізації діяльності державних органів і установ. Істотні структурні реформи були початі для забезпечення гнучкості й ефективності в системі управління [14].

У результаті консолідація державного апарату в системі управління й ліквідація наявних структур, а також реорганізація наявних структур є одним з найбільш ефективних механізмів економії коштів і запобігання бюрократії. У цілому завдяки цим заходам елементи політичної культури в системі управління країни були посилені, а показники виконавчої влади зросли. Під час структурних реформ також 
розглядалося питання забезпечення зайнятості. Відповідним органам було дано конкретне завдання щодо забезпечення повторного працевлаштування працівників призупинених споруд. Структурні реформи забезпечують реалізацію державного управління відповідно до світових стандартів, а також принципів «належного врядування» та «відкритого уряду». Згідно 3 Доповіддю про глобальну конкурентоспроможність Давоського економічного форуму 2019 р., Азербайджан посів 12-е місце 3140 країн за «тягаря державного регулювання» порівняно 3 попереднім роком, випередивши Австрію, Бельгію й Данію. Тільки цей факт свідчить про те, що під керівництвом Президента Ільхама Алієва в країні створено ефективний апарат державного управління [9].

Громадяни є споживачами державних послуг, i, отже, рівень їхньої задоволеності $\epsilon$ ключовим критерієм оцінки роботи державних органів. Просування демократичних реформ у країні, зміцнення їхньої соціальної бази тісно пов'язані з розвитком державної служби. Залучення державних службовців із високою кваліфікацією, громадськими інтересами, здатністю використовувати інформацію й ефективне керівництво для забезпечення функціонування населення й успішного вирішення проблем, є необхідною умовою для управління. Реформи в цій сфері успішно тривають для ефективного функціонування інституту державної служби в нашій республіці. Ця велика робота, розпочата загальнонаціональним лідером Гейдаром Алієвим із підписанням Закону Азербайджанської Республіки «Про державну службу», послідовно здійснюється Президентом Ільхамом Алієвим, і були зроблені реальні роботи. 23 листопада 2018 р. Президент Азербайджанської Республіки Ільхам Алієв видав указ про Стратегію розвитку державної служби в Азербайджанській Республіці на 2019-2025 pp.

«Стратегія розвитку державної служби в Азербайджанській Республіці на 20192025 роки» - це документ, у якому визначені основні цілі, а також середньострокові й довгострокові заходи для досягнення системи державної служби, одного 3 найважливіших інститутів державного управління.

Основною метою стратегії $є$ вдосконалення управління в системі державної служби, формування кадрових ресурсів державних органів, підвищення ефективності роботи державних органів шляхом формування органу державних службовців, заснованого на високих моральних i етичних цінностях, знаннях, навичках $\mathrm{i}$ позитивних особистих якостях [5].

Послідовні реформи для національного розвитку служать поліпшенню управління, а також ефективній підготовці широкого кола фахівців для різних галузей духовної й матеріальної культури, а також формуванню управлінського, відповідального персоналу, що володіє універсальними знаннями, необхідними для ухвалення обгрунтованих соціальних і політичних рішень.

У країні на основі принципів демократії й досвіду країн, що розвиваються демократично, виконуються завдання, які відповідають національним інтересам, такі як модернізація систем управління, державних інститутів, продуктивних сил і зв'язків 3 громадськістю й т.д. Азербайджан збільшив темпи переходу до інноваційного суспільства 3 кращими культурними досягненнями як демократичної країни й 
збереженням розвитку багатої культурної спадщини 3 урахуванням тенденцій розвитку світової цивілізації.

Незалежний Азербайджан зміцнює свої позиції у світовому співтоваристві як провідна держава Південного Кавказу. Невтручання в суверенітет, територіальну цілісність і внутрішні справи інших країн $є$ одним 3 основних принципів зовнішньополітичної стратегії нашої країни. Забезпечення сприятливих умов для взаємовигідного й справедливого співробітництва в системі сучасних міжнародних відносин, реалізація національних інтересів у контексті геостратегічних змін, боротьба 3 тероризмом, безпечні й надійні умови для наших громадян і іноземних бізнесменів.

Успішна реалізація стратегії Президента Ільхама Алієва, закладеної загальнонаціональним лідером Гейдаром Алієвим, засновником сучасного незалежного Азербайджану, відкриває великі можливості для країни.

Великі лідери, які залишили слід в історії, формують державне управління не тільки з урахуванням нинішніх інтересів країни, а й у майбутньому й прагнуть створити оптимальну державну модель, яка формує ідеологічну, політичну, правову й економічну основу державності.

Реформатор національної моделі незалежного Азербайджану Ільхам Алієв не тільки доводить незворотність шляху демократичного прогресу, а й поєднує стабільність 3 інноваціями й сучасністю. Президентський курс реформ заснований на наукових, практичних, сучасних, творчих i ефективних принципах. У зв'язку 3 викликами нових розроблень, установлених у світі й регіоні, виходячи з інтересів національного розвитку, стратегічна важливість довгострокової перспективи має велике значення в економіці Азербайджану, внутрішній і зовнішній політиці, соціокультурній та інших сферах діяльності, також з'явилися нові тенденції. Такі поступові зміни відіграли важливу роль у розвитку суспільства.

Успіх наших геополітичних i геоекономічних ініціатив перед обличчям глобальних загроз зробив нашу модель національного розвитку міжнародним прикладом. Так зазначив шановний Президент Ільхам Алієв: «Сьогодні в світі існує рідкісна модель розвитку Азербайджану. Ми вже можемо говорити про це, тому що ця модель дійсно може зацікавити кожну країну як приклад. Політичні, економічні реформи, незалежна політика, міжрелігійний діалог, національно-релігійна толерантність високого рівня, витривалість, соціальна політика й виконана робота помітна всім» [11].

Перетворення нашої держави у світовий авторитет, позиція реформувальної держави в доповідях міжнародних організацій, ухвалення рішень і резолюцій авторитетними організаціями, що підтримують нашу позицію, розкриває істину: шлях, обраний нашою країною, є правильним і цей шлях веде до нового успіху й світлого майбутнього. 


\section{Література:}

1. «Розпорядження Президента Азербайджанської Республіки про затвердження Національного плану дій щодо сприяння відкритого уряду на 2016-2018 рік». 27 квітня 2016 рік.

2. Розпорядження Президента Азербайджанської Республіки про затвердження Національного плану дій на 2012-2015 рік щодо сприяння відкритого уряду і Національного плану дій по боротьбі з корупцією на 2012-2015 рік. 5 вересня 2012 рік.

3. Азербайджан займає безкомпромісну позицію в боротьбі 3 корупцією. URL : xalqqazeti.com/az/news/15105

4. Сайт Президентської Бібліотеки Канцелярії Президента Азербайджанської Республіки.

5. Стратегія розвитку державної служби в Азербайджанській Республіці на 2019-2025 рік. Розпорядження Президента Азербайджанської Республіки від 23 листопада 2018 року.

6. Сайт Комісії Азербайджанської Республіки по Боротьбі з Корупцією. URL : commissionanticorruption.gov.az

7. Стратегічна дорожня карта для перспектив національної економіки Азербайджанської Республіки. 6 грудня 2016 рік.

8. Розвиток ненафтового сектора в Азербайджані: економічні реформи і їх результати URL : a-r.az/article/13554

9. Нова структра управління в Азербайджані. URL : http://www.realtv.az/news/az/11068/azerbaycanda-yeni-idareetme-strukturu. https://az.strategiya.az/ news.php?id=125909

10. Багірлі Л. Людський капітал як фактор соціально-економічного розвитку. URL : https://az.strategiya.az/news.php?id=125909

11. Сьогодні в світі існує Азербайджанська рідкісна модель розвитку. URL : İki sahilikisahil.az/post/news-30905

12. Джабраїлов Рафаель. Людина, яка стала національним надбанням народу // Газета «Азербайджан», 08 травня 2013 рік.

13. Доповідь Світового банку «Doing Business 2019» проголосив Азербайджан найкращою країною в світі, що реформується. 31.10.2018.

14. Гасанов Алі. Ільхам Алієв: чудовий рік нового президентства. URL : http://ar.az/article/14836

15. Ідеї Гейдара Алієва і стратегія глибоких реформ. Баку, CBS 2017, 736 с.

16. Ільхам Алієв: чудовий рік нового президентства. URL : http://a-r.az/article/14836

17. Людський фактор, людський капітал. URL : ikisahil.az/post/news-68004

18. Революційний указ в судовій системі. URL : ikisahil.az/post/mehkeme-huquqsistemindeinqilabi-ferman

19. Мамедов Ф. Т. Культурологія, культура, цивілізація. Баку : «OL» MMC, 2016. 260 с.

20. Мамедов Ф. Т. Культура Управління. Досвід зарубіжних країн. Баку : «Apostrof».

21. Мамедзаде Ільхам. Хід і стратегія реформ Ільхама Алієва. URL : Газета «Народ», 2019, 13 квітня, №79, с. 3.

22. Оголошено результати моніторингу та оцінки стратегічних дорожніх карт URL : http://iqtisadiislahat.org/news/ strateji_yol_xeritelerinin_monitorinq_ve_qiymetlendirme_neticeleri_ aciqlandi-743)

23. Сулейманова Е. Фактори прав людини в удосконаленні державного будівництва та управління. «Державне управління», 2014, №3(47), с. 97-116. 


\section{Abdulali Abdullayev}

\section{STRUCTURAL REFORMS IN AZERBAIJAN AS PART OF THE EFFICIENCY OF DEMOCRATIC GOVERNANCE}

The article analyzes structural reforms in Azerbaijan as part of the effectiveness of democratic governance. It is underlined that a new judicial system was created under the leadership of the national leader Heydar Aliyev; constitutional control; institutions empowered by human rights, based on the principle of democratic justice; the activities of law enforcement agencies have been improved; media activities have been expanded; effective safeguards have been put in place to ensure citizens' rights.

Keeping up reforms in the direction of human capital development in Azerbaijan is vital for improving the quality of education and creating a flexible mechanism for managing relations «science - education - production».

The principle of paralleling economic, political and legal reforms over the last 10 years is a fundamental basis for the process of democratization in Azerbaijan and the adaptation of liberal values of society.

Progressive development measures include enhancing the country's economic potential, developing the non-oil sector, creating the conditions for workplaces, developing entrepreneurship, increasing substantially the volume and focus of social services, poverty reduction, etc.

The depth of reforms in Azerbaijan, the progress made in combatting corruption, the larger scale of the institutional changes and the measures taken to fight against corruption lead to the fact that Azerbaijan scores higher in the Corruption Perceptions Index (CPI).

Azerbaijan has increased the pace of transition to an innovative society with better cultural achievements as a democratic country and preserving the development of a rich cultural heritage, taking into account the tendencies of the development of world civilization.

Keywords: reforms, public administration, public authorities, national development, innovation process.

\section{Абдулалі Абдуллаєв}

\section{СТРУКТУРНІ РЕФОРМИ В АЗЕРБАЙДЖАНІ ЯК ЧАСТИНА ЕФЕКТИВНОСТІ ДЕМОКРАТИЧНОГО УПРАВЛІННЯ}

У статті проаналізовано структурні реформи в Азербайджані як частину ефективності демократичного управління. Підкреслено, що під керівництвом загальнонаціонального лідера Гейдара Алієва було створено нову судову систему; конституційний контроль; установи, уповноважені із прав людини, засновані на принципі демократичного правосуддя; удосконалено діяльність правоохоронних органів; розширено діяльність засобів масової інформації; сформовано ефективні захисні механізми щодо забезпечення прав громадян. 
Продовження реформ за напрямом розвитку людського капіталу в Азербайджані $\epsilon$ дуже важливим для поліпшення якості освіти та створення гнучкого механізму управління відносин «наука - освіта - виробництво».

Принцип паралелі економічних, політичних і правових реформ за останні 10 років становить фундаментальну основу процесу демократизації Азербайджану та в цілому адаптації ліберальних цінностей суспільства.

До прогресивних заходів щодо розвитку належить посилення економічного потенціалу країни, розвиток не нафтового сектору, створення умов для відкриття робочих місць, розвиток підприємництва, збільшення в істотному порядку обсягу та націленості соціальних послуг, скорочення бідності й т. д.

Глибина реформ в Азербайджані, прогрес, досягнутий в боротьбі з корупцією, більший масштаб інституційних змін і заходи, прийняті для боротьби 3 корупцією, призводять до того, що Азербайджан отримує більш високі показники в «Індексі сприйняття корупції» (Corruption Perceptions Index, CPI).

Азербайджан збільшив темпи переходу до інноваційного суспільства 3 кращими культурними досягненнями як демократичної країни і збереженням розвитку багатої культурної спадщини з урахуванням тенденцій розвитку світової цивілізації.

Ключові слова: реформи, державне управління, державні органи, національний розвиток, інноваційний процес.

Абдуллаєв Абдулалі - доктор філософії з юридичних наук, доцент юридичної кафедри Академії державного управління при Президентові Азербайджанської Республіки.

e-mail: abduleliabdullayev@mail.ru

Надійшла до редакції 18.11.2019. Розглянута на редколегії 19.11.2019.

\section{Рецензенти:}

Кандидат політичних наук, доцент, доцент кафедри права гуманітарного факультету Національного аерокосмічного університету ім. М. С. Жуковського «Харківський авіаційний інститут» Ковальова І. І.

Кандидат юридичних наук, доцент, доцент кафедри права гуманітарного факультету Національного аерокосмічного університету ім. М. С. Жуковського «Харківський авіаційний інститут» Гуцу С. Ф. 